University of Nebraska - Lincoln

DigitalCommons@University of Nebraska - Lincoln

Agronomy \& Horticulture -- Faculty Publications

Agronomy and Horticulture Department

$1-1935$

\title{
Measurement of Run-Off and Soil Erosion by a Single Investigator
}

J. E. Weaver

University of Nebraska-Lincoln

Follow this and additional works at: https://digitalcommons.unl.edu/agronomyfacpub

Part of the Plant Sciences Commons

Weaver, J. E., "Measurement of Run-Off and Soil Erosion by a Single Investigator" (1935). Agronomy \& Horticulture -- Faculty Publications. 457.

https://digitalcommons.unl.edu/agronomyfacpub/457

This Article is brought to you for free and open access by the Agronomy and Horticulture Department at DigitalCommons@University of Nebraska - Lincoln. It has been accepted for inclusion in Agronomy \& Horticulture -Faculty Publications by an authorized administrator of DigitalCommons@University of Nebraska - Lincoln. 


\section{ECOLOGY}

\begin{tabular}{llr}
\hline \hline Vol. XVI & January, 1935 & No. 1 \\
\hline
\end{tabular}

\section{MEASUREMENT OF RUN-OFF AND SOIL EROSION BY A SINGLE INVESTIGATOR *}

J. E. Weaver and War. Noll.

University of Nebraska

That run-off water and soil erosion have become problems of both local and national importance is widely recognized. In fact soil erosion over at least half of the United States has reached the proportions of a national menace. To study quantitatively the amount of run-off and erosion from different topographical areas and types of soil under various climates as well as the quantities of soil lost under different methods of cropping, terracing, etc., the government has established Federal erosion stations. These are located in various widely separated areas. The accumulated results obtained at these stations are now finding an important place in the literature. Similar studies by certain agricultural experiment stations are also of great value. Results obtained by Duley and Miller ('23) in Missouri over a period of several years are indicative of the effect of herbaceous cover on run-off and erosion. The U. S. Forest Service has marle similar extensive and commendable studies in relation to grazing. For example, a study of surface run-off and erosion in relation to overgrazing has been carried on for a long period of years on the Manti National Forest, in Utah (Sampson and Weyl, '18; Forsling, '31). Bates and Zeasman ('30), using erosion traps in Wisconsin, made a study of run-off rates under different conditions of forest, pasture, and cultivated fields. ${ }^{1}$

\section{Need of Individual Experimentation}

Practically all of these investigations, except those in relation to grazing, deal only incidentally with native vegetation and are concerned primarily with crops and systems of cropping. Therefore they afford little aid to the stu-

* Contribution from the Department of Botany, University of Nebraska, No. 88.

${ }^{1}$ It was from their work that the idea for the apparatus described in this paper was obtained. 
dent of natural vegetation in studies concerning water relations. Moreover, results obtained from a particular soil type under a given set of climatic conditions will not apply except in a very general way to other soils and climates. Hence, in studying the water relations of various types of natural vegetation, there is a need of determining run-off and any consequent erosion directly in each type.

Water content of soil is not only a factor affecting plants and vegetation directly but one of the most important factors. This is true not only where water is deficient but also where it is in excess, as a result of the concomitant factor of decreased aeration. In the rougher portions of the mixed prairie, for example, the higher lands may support a nearly pure growth of Bouteloua gracilis and Bulbilis dactyloides and the lower midslopes Andropogon scoparius. But in ravines where the natural rainfall is supplemented by run-in water, Andropogon furcatus or Panicum virgatum may flourish. In tact, the run-off from higher ground may even furnish conditions suitable for the growth of Typha latifolia, Scirpus zalidus and other hydrophytes. Although one may obtain the actual water content from week to week by soil sampling, a clear picture of the quantitative distribution of water over the surface of the soil-the movement from higher lands to the lowlands-can be had only by actually measuring run-off. In many areas differences in vegetation can be accounted for only upon the basis of such movement. Frequently it occurs in places and amounts quite unexpected. In semi-arid and arid climates only small amounts of such water movement may exert a profound effect upon the type of vegetation. Hence a complete study of the water relations should include measurement of run-off as well as water accumulation or run-in from surrounding areas. The catch basin or interceptometer may be used for both of these purposes. It has the distinct advantages that it can be installed and operated by a single investigator along with other ecological apparatus (which should include a rain gauge), and that it is permanent and inexpensive.

\section{The Interceptometer}

This type of interceptometer consists of a box of no. 22 galvanized iron 3 feet long, 8 inches wide, and 18 inches deep. It is well braced inside and furnished with a hinged, sloping top, open in front, as shown in figure 1. The cost of the box, which can be made by a local tinner, is approximately eight dollars.

After selecting the station for installment, an excavation slightly larger than the interceptometer is made at right angles to the slope. This should be just long enough to receive the container, about 10 inches wide and 18.5 inches deep, with the front (upper) wall perpendicular and smooth. The front side of the interceptometer is then fitted tightly against this wall with the upper edge about 0.5 inch below the soil surface. Soil is then tightly tamped, in filling the excavation, against the entire back wall of the container, which is thus held firmly in place. During rains the water running from the back- 
wardly sloping top keeps this soil wet and firm. But during long periods of dry weather it is necessary to retamp the soil to keep the front wall tightly in place.

An area 3 feet wide and 33.3 feet long is enclosed by long strips of no. 22 galvanized iron or planed inch boards 6 inches in width. These are placed on

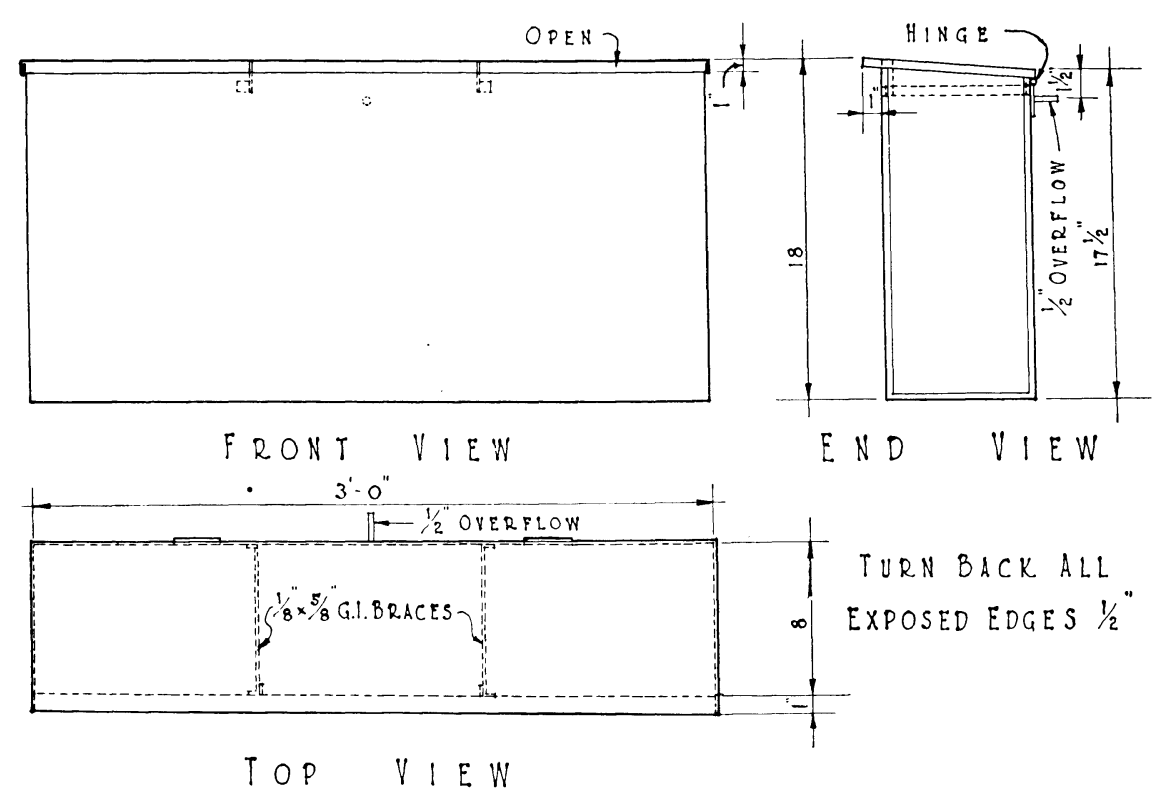

FIG. 1. Drawings showing the structure of the interceptometer.

edge in the soil to a depth of 3 to 4 inches. In the case of the boards this is best done by laying them on their side so that the outer edges include exactly 100 square feet. A shallow, narrow trench with straight walls is then dug to the proper depth, the boards placed on edge in it and held firmly by nailing to stakes securely driven into the soil just outside of the area. The trench is then filled and tamped from the outsicle, thus holling the framework securely in place. Thus run-in water is excluded from the experimental area.

Water running down inside the enclosed area finds its way into the interceptometer, entering under the top which is about 0.5 inch above the surface of the soil. The accumulated water should be measured and removed each day, or after every shower if desirable. In case this can be done only once each week, as at distant stations, no loss will occur if precaution has been taken to place a small quantity of oil in the interceptometer. The oil film spreading over the water prevents loss by evaporation. If the interceptometer is found to be too small to hold the run-off, a spout 0.5 inch in diameter and 2 inches long may be soldered to an opening in the back about an inch from the top. This may be connected by rubber tubing to a covered overflow container sunk 
in the soil just back of the interceptometer. Where the roily or muddy water indicates soil erosion, a settling tank of appropriate size may receive the contents of the interceptometer. After settling, the clear water may be siphoned off, the sediment air dried, and thus the quantity of eroded soil determined.

An area of 100 square feet is of convenient size for comparative study of different types of grassland and the effects of clipping, grazing, or burning upon run-off. The amount of run-off and erosion from melting snow, which is often consiclerable, may also be measured. It is also convenient for the comparative study of grassland and various cultivated crops such as corn, wheat, alfalfa, or of fallow land The length of the enclosure may be increased or decreased where it is desirable to determine the effect of the length of the slope on run-off and erosion (Duley and Ackerman, '34). In forested areas or those covered with scrub, larger enclosures may be more desirable in a study of the effects of thinning, cutting, burning, or denuding. The principle, however, remains the same. It is always desirable in making comparative studies of different types of natural or modified vegetation to have comparable conditions of slope and soil so far as is possible.

\section{Illustrative Results}

A number of interceptometers have been used during the past two years. Although the precipitation has been unusually light, some illuminating results have been obtained. One interceptometer was installed in prairie on a hillside of Lancaster loam with a slope of $10^{\circ}$ and another 30 feet distant on a similar slope in a pasture (cf. Weaver, ct al, '35). The climax prairie of little bluestem had been mowed annually; the pastured area was similar only that it had been closely grazed for a period of two years and also ciuring the period of the experiment. Not only was the vegetation removed close to the soil but the soil itself was trampled.

A torrential April shower of .47 inch resulted in heavy run-off. This amounted to 15 liters in the prairie and 46 liters in the pasture (table I). Heavier rains on July 7 and 8 , but falling over a period of several hours, resulted in 4.6 and 8.5 times as much run-off in the pasture as in the prairie where it was 1 liter in both cases. Showers of equal amounts but of different intensities on June 8 and 14 resulted in considerable differences in run-off and showed that under certain conditions practically all of the water may be absorbed even on a $10^{\circ}$ slope.

On August 31, .25 inch and .32 inch of rain fell, each during one hour in a rain storm totaling .82 inch. Run-off was high. A day later, .47 inch of a .51 inch rain fell in an hour. It resulted in slightly less run-off in the pasture and less than half as much in the prairie (table I). During an .84 inch rain, two days later when 4 inch fell during a single hour, the pasture lost 19.9 liters but the prairie only 1.6. 
TABLE I. Run-off from pasture and prairie

\begin{tabular}{lcccc}
\hline \hline \multicolumn{2}{c}{ Date } & \multicolumn{2}{c}{ Rainfall, } & \multicolumn{2}{c}{ Run-off, liters } \\
inches & Pasture & Prairie \\
\hline April 29, 1933 & .47 & 46.0 & 15.0 \\
July 7,, “ & .65 & 4.6 & 1.0 \\
July 8, “ & .54 & 8.5 & 1.0 \\
June 8,1934 & .64 & 7.0 & 4.0 \\
June 14, “ & .64 & 1.8 & 1.3 \\
June 17, “ & .27 & 0.0 & 0.0 \\
June 22, “ & .57 & 1.7 & 0.8 \\
Aug. 31, “ & .82 & 14.5 & 8.3 \\
Sept. 1, “ & .51 & 13.7 & 2.9 \\
Sept. 3, “ & .84 & 19.9 & 1.6 \\
\hline
\end{tabular}

A second installation was made for the purpose of comparing run-off in a virgin prairie of little bluestem and in an adjoining area that had been broken and cropped for a period of 6 years. The crop of winter wheat was removed from a part of the field by hoeing. This is clesignated as fallow field. In all cases the slope was $5^{\circ}$. Readings were made only when the soil was unfrozen.

On December 2, when the crop of winter wheat stabilized the dry, loose field soil, the run-off from a 1.3 inch rain was less than that in the mowed prairie (table II). A rainfall of 1.47 inches, on December 3, after the surface soil had been thoroughly wet, resulted in more than twice as much runoff in the field of wheat as in the native grassland. When the soil was again very dry (June 8), the small run-off in the prairie exceeded that in the field during a .58 inch rain. But on June 14 a rain of .87 inch resulted in greater water loss from both the field and fallow land.

The relatively heavy rains of August 31 and September 1 resulted in high run-off except in the prairie. The amount lost from the fallow land greatly exceeded that lost from the wheat stubble (table II). During the inch of rain on September 3, practically all of the water was absorbed in the prairie, 37 liters ran off from the stubble field, and twice this amount from the fallow land. Losses by erosion from these rains in the two field plots aggregated 1.5 and 5.5 kilograms, respectively.

Table II. Run-off from prairie, zuheat field, and fallow land.

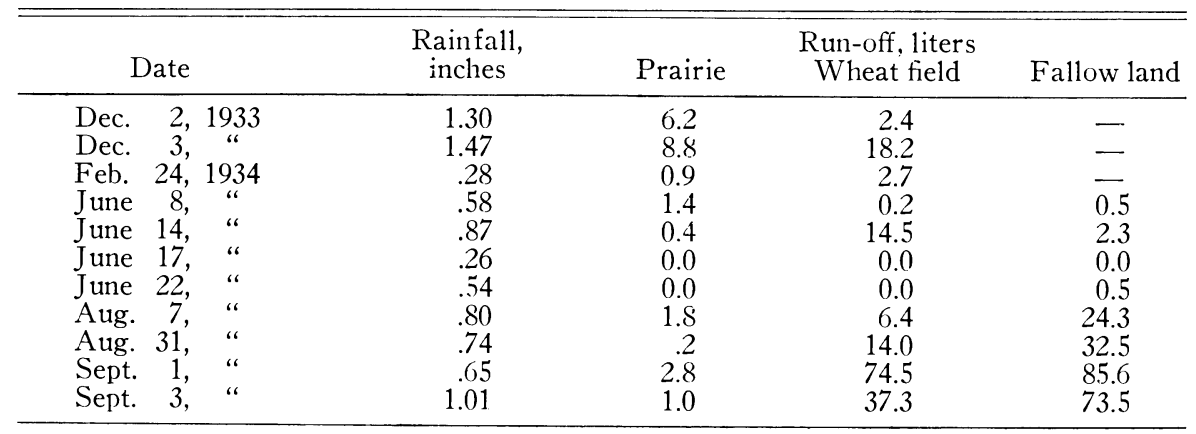




\section{Experimental Watering}

Since little rain fell during the extremely dry summer of 1934, some experiments were made by adding water from sprinklers, thus imitating rain. Such experiments have numerous advantages over natural rainfall. By the cooperation of several workers, water may be applied at any desired rate and during any desired period of time. The behavior of the soil surface in relation to the intake of water may be directly observed under favorable conditions, the time when run-off or erosion begins ascertained, the relative turbidity or clearness of the water observed, and the period of run-off after cessation of watering determined.

In one experiment 7.5 inches of water were applied to the prairie soil during a period of three days and somewhat smaller amounts to wheat land and fallow field. The water was hauled in 55 gallon steel barrels and sprinkled uniformly over the 100-square-foot areas by 5 students, each watering an area of 20 square feet. The run-off water and eroded soil were removed, placed in settling tanks and the amount of erosion determined. The results are summarized in table III.

The watering on July 3 showed that the very dry surface soil of the prairie (with a water content below the hygroscopic coefficient) absorbed the three inches of water during 1.5 hours with only 1.5 per cent run-off. There was no erosion. The fallow field absorbed even better than the prairie during the first half hour, but soon the soil pores became partially blocked so that 18.1 per cent of the total water was lost together with approximately .008 of the surface inch of the air dried soil. ${ }^{2}$ Sampling the following morning showed that the water had penetrated to an average clepth of 14 inches in the prairie."

The two inches of water applied on July 4 were absorbed by the prairie with only 5.5 per cent run-off and no erosion. The following morning the soil was wet to a depth of 16 inches near the upper end of the area and 21 inches near the foot. The fallow field lost 38.8 per cent of the water from the single inch applied and .005 of the surface inch of soil.

Water was applied to the wheat stubble on July 4 in the same amounts and at the same rate as in the prairie on July 3. The original water content of the first foot was quite as low as that in the grassland. It may be noted that the run-off was very much greater in the field after each inch of applied water; the total run-off for the three inches was 16.9 per cent. Moreover .004 of an inch of soil was removed from the surface of the field. The following morning the water had penetrated 11 inches at the lower end of the slope but only 7 at the upper end. This averaged 5 inches less than in the prairie.

With the application of a fourth inch of water to the stubble field on July 5 , run-off was greatly increased, and 43.9 per cent of the fourth and fifth inch

2 Run-off in all cases includes the amount of eroded soil.

${ }^{3}$ The holes made by sampling with a Briggs' geotome were refilled with dry soil firmly tamped. 


\begin{tabular}{|c|c|c|c|c|c|c|}
\hline 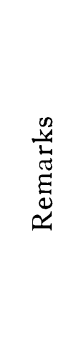 & 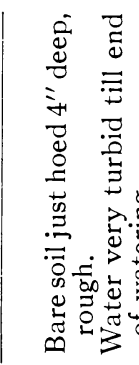 & 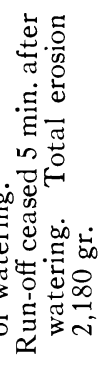 & \multicolumn{2}{|c|}{ 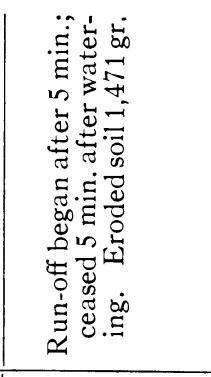 } & \multicolumn{2}{|c|}{ 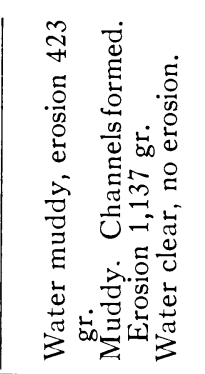 } \\
\hline 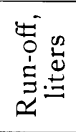 & $\hat{0} \stackrel{\sim}{\sim}$ & $\underset{\infty}{\mathscr{1}}$ & $\stackrel{\circ}{\text { ì }}$ & & 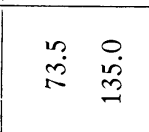 & $\tilde{a}$ \\
\hline 咅离 & $\neg$ & - & - & & $\rightarrow \rightarrow$ & - \\
\hline$\stackrel{\varrho}{\Xi}$ & 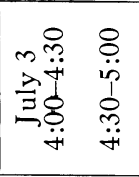 & $\begin{array}{l}0 \\
0 \\
\ddot{p} \\
0 \\
\ddot{n}\end{array}$ & 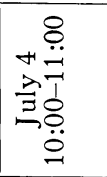 & & 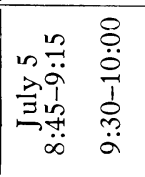 & 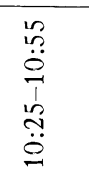 \\
\hline$\frac{\mathscr{J}}{2}$ & 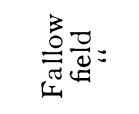 & $=$ & 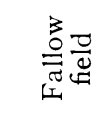 & & 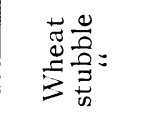 & 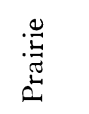 \\
\hline 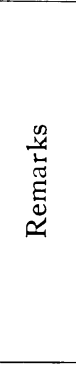 & 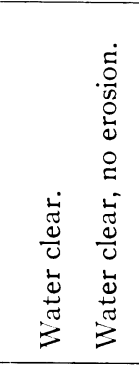 & 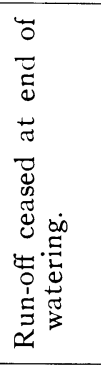 & 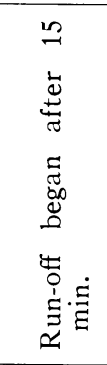 & 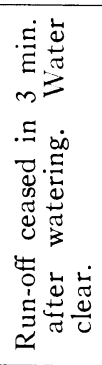 & 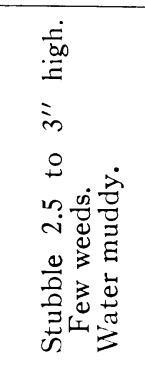 & 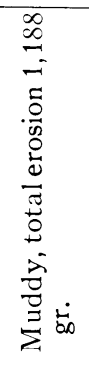 \\
\hline 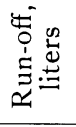 & $\stackrel{+}{\rightarrow} \stackrel{\circ}{\circ}$ & in & $\stackrel{?}{?}$ & $\begin{array}{l}0 \\
\infty \\
\sim\end{array}$ & $\stackrel{0}{\stackrel{0}{=}} \stackrel{\text { m }}{\stackrel{F}{F}}$ & $\begin{array}{l}\text { in } \\
100\end{array}$ \\
\hline 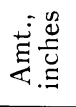 & - & - & - & - & $\rightarrow$ & - \\
\hline$\stackrel{g}{\Xi}$ & 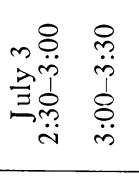 & $\begin{array}{l}\stackrel{\rho}{0} \\
\dot{+} \\
0 \\
\ddot{n} \\
\ddot{n}\end{array}$ & 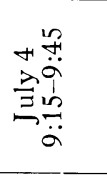 & $\begin{array}{l}0 \\
0 \\
\ddot{0} \\
o \\
\stackrel{0}{0}\end{array}$ & 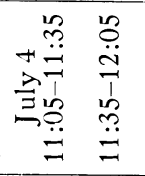 & 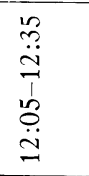 \\
\hline$\frac{\mathscr{U}}{\tilde{\sigma}}$ & : & $=$ & : & $=$ & 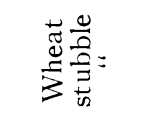 & $=$ \\
\hline
\end{tabular}


was lost in this manner. Also the additional two inches of water had removed .005 of the surface inch of soil. While 5 inches of water wet the prairie to an average depth of 18 inches, average water penetration in the wheat field did not exceed 12 inches.
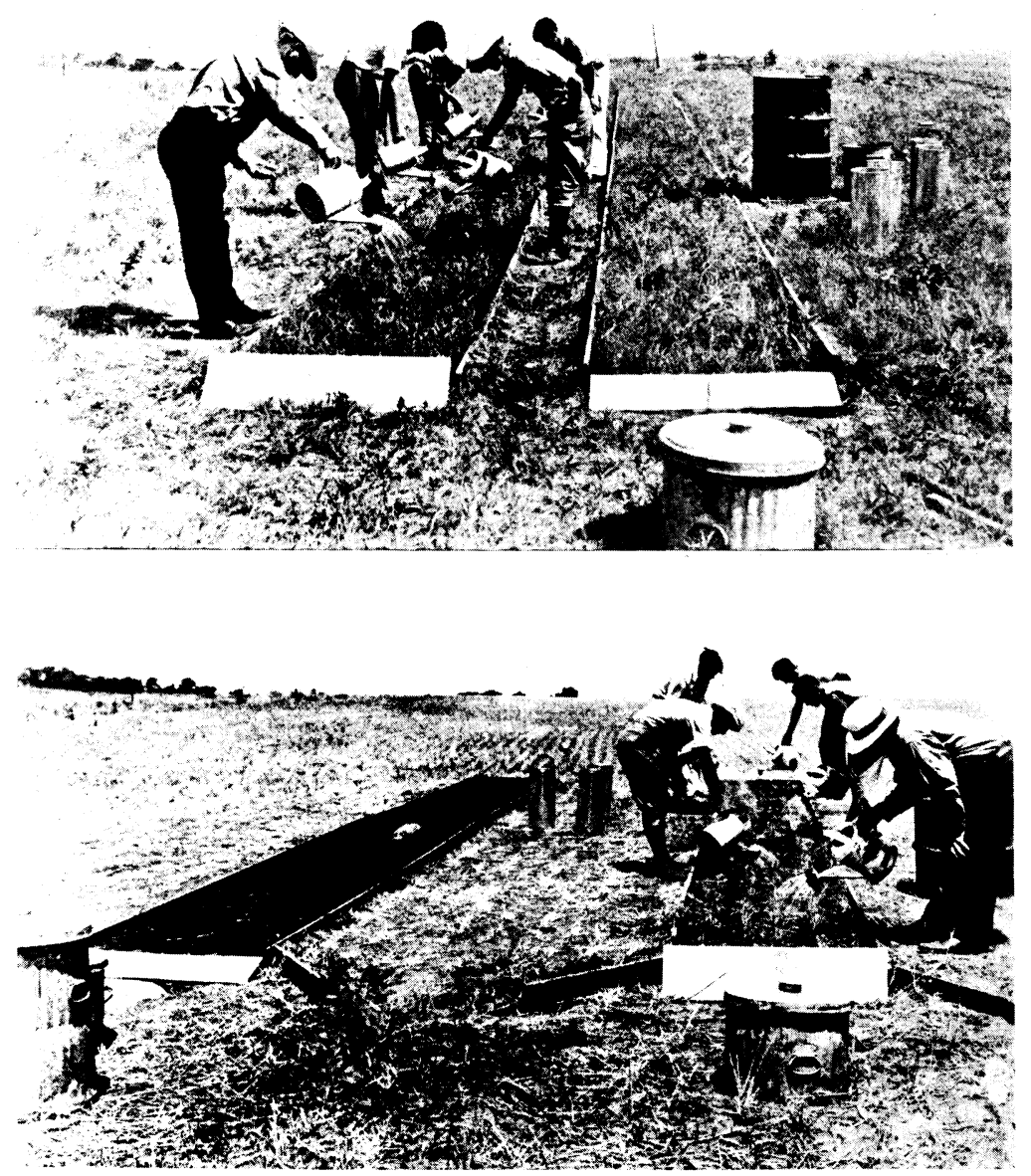

Fig. 2. (Above) Measuring the run-off on a 5-degree slope in Andropogon scoparius prairie by the direct application of an inch of water every 30 minutes.

FIG. 3. (Below) Determining comparative run-off and erosion on a 5-degree slope from wheat stubble and fallow land.

Soil samples showed that the field soil held 4 per cent more water in the surface 4 inches five days after the 5 inches of water were applied than did the prairie after a single day. But in the 4 to 12 inch layer the prairie soil had 7 per cent more water than did the field soil. The higher water content of the moist portion of the second foot of soil was also significantly greater in the prairie. 
The prairie soil had been so thoroughly depleted of its moisture that the 7.5 inches of water increased the water content only in the first 3 feet. Samples of dry soil taken during the experiments to depths of 3 feet at a distance of 3 inches outside of the enclosed areas showed that there was little lateral movement of the soil water.

Summarizing, the total run-off resulting from the application of 5 inches of water was 3.1 per cent in the prairie, 27.7 per cent in the stubble field, and 23.3 per cent in the fallow ground (where only 4 inches were applied.) Erosion from the prairie was practically nil, .009 inch of the surface from the stubble field and .013 of the surface inch from the fallow land had washed away.

One and one-half more inches of water added to the prairie during a period of 45 minutes on July 7 resulted in a run-off of only 20.5 liters.

Similar experiments were performed in the prairie and pastured area (table IV). A study of the results shows that in the prairie run-off began later in all cases, was smaller in amount, and ceased sooner after the total amount of water or any portion of it was applied. This resulted partly because of the greater interference to water movement afforded by the denser ungrazed vegetation, but perhaps chiefly to the greater porosity of the untrampled soil. The pasture had been grazed (or cut) so closely for three years that the weakened plants had partially lost their power of binding the soil, some of which would have been removed by torrential rains. On July 7 the total run-off for the 2 -inch watering in the pasture was 11.3 per cent, but that in the prairie only 4.1 per cent. The third inch of water in the pasture gave a run-off of 30.2 per cent. On July 19 the percentages of run-off for the two inches of water added in the pasture and prairie were 8.6 and 2.1 per cent, respectively.

\section{Value of Experiments to Students}

A study of run-off and erosion caused by natural rainfall and their direct measurement by applying water are of much value in teaching. Students have opportunity to see these processes actually at work. They learn that they are directly connected with the amount of precipitation but especially with the manner in which it falls. The effect of the plant cover upon reducing the force with which the raindrops strike the soil may be clearly seen. Likewise, the beating of the raindrops upon the bare soil, the shifting of the soil particles and consequent closing of the pore spaces, and the compaction of the soil may be observed. This focuses attention upon soil structure. The accumulation of the excess water and its rumning off, frequently with the formation of little channels, becomes a reality. They will observe that in sheet erosion loss of materials is mostly from the clark surface soil which is high in organic matter and rich in plant food-materials. Attention is called to the loss of important nutrient elements, which may often be more serious than the loss by removal of crops. 
J. E. WEAver AND WM. Noll Ecology, Vol. 16, No. 1

\begin{tabular}{|c|c|c|c|c|}
\hline 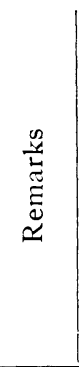 & 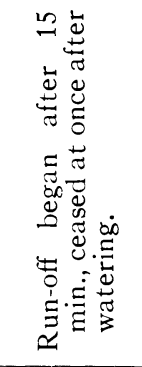 & 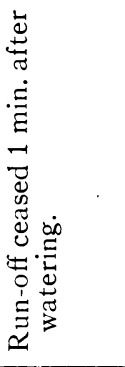 & 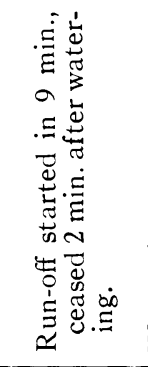 & 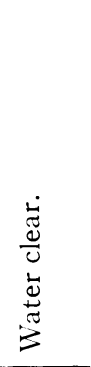 \\
\hline 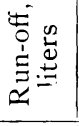 & $\stackrel{\circ}{\circ}$ & $\stackrel{m}{\stackrel{9}{g}}$ & $\overrightarrow{6}$ & $\hat{m}$ \\
\hline 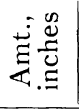 & - & $\rightarrow$ & $\rightarrow$ & - \\
\hline$\stackrel{\Xi}{\Xi}$ & 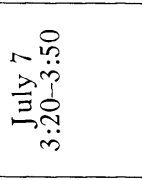 & 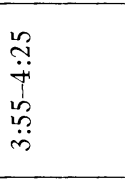 & 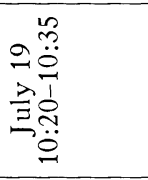 & 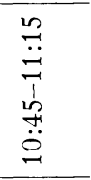 \\
\hline $\begin{array}{l}\frac{\mathscr{E}}{2} \\
\frac{\pi}{2}\end{array}$ & 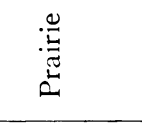 & $=$ & 总 & $=$ \\
\hline 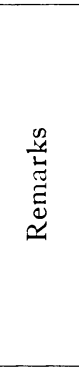 & \multicolumn{2}{|c|}{ 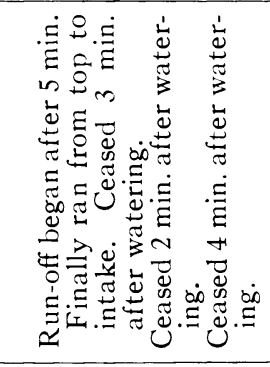 } & \multicolumn{2}{|c|}{ 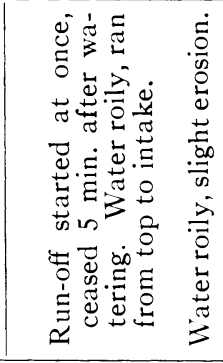 } \\
\hline 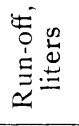 & $\stackrel{\infty}{\stackrel{0}{q}}$ & 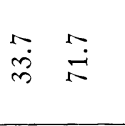 & $\stackrel{\text { }}{\stackrel{\sim}{े}}$ & $\begin{array}{l}m i n \\
\dot{i} \\
\dot{i}\end{array}$ \\
\hline 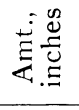 & - & --7 & - & $-r^{n ?}$ \\
\hline$\stackrel{\mathscr{\Xi}}{\Xi}$ & 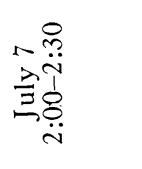 & 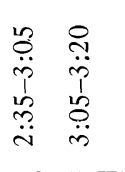 & 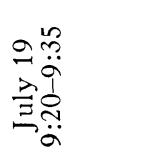 & 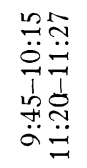 \\
\hline $\begin{array}{l}\stackrel{\mathscr{J}}{2} \\
\frac{\pi}{2}\end{array}$ & 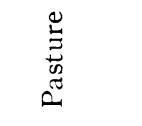 & $==$ & 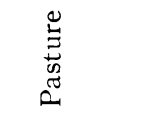 & $=:$ \\
\hline
\end{tabular}


The quantities of water lost during torrential rains even from small areas are impressive and naturally lead to calculations of the amounts running off from whole hillsides, the total amount of soil removed, the effects of this runoff water in forming gullies and ditches, and of the sediment finally silting up the fertile lowlands. The water is lost to ground storage; the deepening of gullies and ditches lowers the water table, which results in a constant tendency of the water in the upper layers to sink to lower levels. The habitat is gradually changed. The hard, compact, poor absorbing surface left after severe erosion is always impressive. That the water holding capacity is reduced is not difficult to understand. It may now be better realized that erosion can be held largely accountable for disastrous floods, on the one hand, and drought on the other. It is easier to comprehend that " most of the wornout lands of the world are in their present condition because the surface soil has washed away, and not because they have been worn out by cropping" (Duley, '24).

Conversely, on vegetated areas the effects of the bases of the plants in retarding the water movement may be seen. The retarding influence of the myriads of tiny dams and terraces, formed by the fallen leaves, stems and other debris, upon water movement may be learned. The porosity of the forest or moist grassland soil into which the water sinks is impressive. It accounts for the fact that on fully vegetated lands practically no erosion occurs except, possibly, during storms of unusual violence, and even then erosion is seldom serious. But on bared or sparsely vegetated slopes both run-off and erosion may occur after relatively light showers. It soon becomes clear that the most important factor tending to decrease erosion in non-tilled lands is the maintenance of a plant cover. Students learn that run-off without erosion may occur on land with a stabilized plant cover; that erosion usually increases with a decrease in plant cover, and is greatest from bared soil. Of first importance is the effort to reestablish and conserve the optimum cover of vegetation. The more complete the cover the more adlaquate is the protection against soil erosion. Forsling ('31) has shown, for example, that " the increase in the density of vegetation from 16 to 40 per cent of a complete cover and the replacement of certain plants by others with more extensive and more fibrous root systems reduced the rainfall surface run-off 64 per cent and rainfall erosion 54 per cent." This results in the conclusion that, so far as possible, man should keep a crop on his cultivated fields at all times.

\section{Literature Cited}

Bates, C. G., and O. R. Zeasman. 1930. Soil erosion--a local and national problem. Wisc. Agr. Exp. Sta. Res. Bull. 99.

Duley, F. L. 1924. Controlling surface erosion of farm lands. Mo. Agr. Exp. Sta. Bull. 211.

Duley, F. L., and M. F. Miller. 1923. Erosion and surface run-off under different soil conditions. Mo. Agr. Exp. Sta. Res. Bull. 63. 
Duley, F. L., and F. G. Ackerman. 1934. Run-off and erosion from plots of different lengths. Jour. Agr. Res. 48: 505-509.

Forsling, C. L. 1931. A study of the influence of herbaceous plant cover on surface run-off and soil erosion in relation to grazing on the Wasatch Plateau in Utah. U. S. Dept. Agr. Tech. Bull. 220.

Sampson, A. W., and L. H. Weyl. 1918. Range preservation and its relation to erosion control on western grazing lands U.S. Dept. Agr. Bull. 675.

Weaver, J. E., V. H. Hougen, and M. D. Weldon. 1935. Relation of root distribution to organic matter in prairie soil. Bot. Gaz. 96: 